\title{
The Adaptation and Transfer of Advertising Design Ideas in Shanghai in the Period of the Republic of China
}

\author{
Huang Zhan ${ }^{1, *}$ \\ ${ }^{1}$ Academy of Fine Arts, Nanjing Xiaozhuang University, Nanjing, Jiangsu, China \\ "Corresponding author. Email: huangzhan@126.com
}

\begin{abstract}
In the period of the Republic of China, advertising design in Shanghai underwent adaptive development and evolution, forming a unique advertising idea which is not only reflected in the design system but also contained in the social system at that time. This kind of advertising design with obvious design progress and historical background exists not only in the adaptation of Western advertising but also in the reference of local advertising, involving both the adaptation of outdoor advertising related design practice, theory and changes and the transfer of traditional design methods. It becomes the summary of researches on outdoor advertising in the period of the Republic of China, plays a due connecting role in the social transition period and is reflected in the design influence of outdoor advertising itself.
\end{abstract}

Keywords: The period of the Republic of China, Shanghai, Advertising design, Adaptation.

\section{INTRODUCTION}

"The global dissemination and popularization of modern design throughout the 20th century is like a huge cultural vortex, including the promotion, influence, imitation, as well as the conflict, selection, absorption and recreation... The dissemination of modern design in the East is also a complex process of relationship generation and culture redefinition". ${ }^{1}$ This cognition in culture dissemination at the beginning of the 20th century can be deduced as a process of "generation - spread - influence absorption - promotion". This coherent process interprets and reveals the redefinition of Shanghai advertising design under the "symbiosis" of foreign impact and internal culture in the period of the Republic of China.
Chen Xiangbo, Xu Ping, Zhou Bo, Huang Zhicheng; Guanshanyue Art Museum, Central Academy of Fine Arts. Documentary of the 20th Century Chinese Graphic Design [C]. Guangxi Fine Arts Publishing House. May 2012. p8.

\section{THE BACKGROUND OF ADVERTISING DESIGN IDEAS IN SHANGHAI IN THE PERIOD OF THE REPUBLIC OF CHINA}

Advertising design ideas in Shanghai during the Republic of China had obvious characteristics of the times. By eliminating abstract concepts and focusing on the ontological objects in this process, it is available to clearly recognize the interaction between Shanghai culture, art, and art in the same period, especially the influence and feedback of commercial art under the Western capitalist system.

At that time, this influence was posed to Chinese commercial art from many aspects and angles, and further to the overall outdoor advertising design. Regarding the influence of Shanghai industrial and commercial arts, a discussion can be started from the various handicraft workshops opened in Tou-Se-We in the early days. Tou-Se-We Press was a printing, publishing and sales house early established by foreign Catholic missionaries in Shanghai. In addition to printing a large number of religious books, it also printed a great deal of modern natural science copies, playing certain role in the dissemination of 
Western culture and the emergence of early design. Relying on exquisite binding and layout and picture poster, those propaganda media not only played a key role in the dissemination of industrial and commercial arts at that time, but also brought advanced Western technological civilization and daily necessities to the eyes of Chinese people. Obviously, Tou-Se-We Press was confident in propagating Western science and culture among Chinese people and believers while propagating beliefs of the "Holy Religion". As priest Joseph de la Serviere said, "Tou-Se-We Press is famous in the Far East. All the books published by it paved a way for communication between people with yellow skin and people with other colors". ${ }^{2}$ At the same time, Tou-SeWe Press belonged to Tou-Se-We Art Gallery which could also be called an "early Western art education institution in China". Although the art gallery aimed to spread religious art, it also introduced a set of comprehensive and formal Western art education method and system for the first time, including watercolor painting, pencil painting, and brush painting, charcoal painting, oil painting and other subjects. Many famous artists in modern and contemporary China such as $\mathrm{Xu}$ Yongqing, Zhou Xiang, Ding Song and Zhang Chongren successively studied art here. And many of them are pioneers and enlighteners of Chinese modern art. ${ }^{3} \mathrm{Up}$ to the period of the Republic of China, these artistic pioneers had been able to skillfully apply Western commercial art forms to creating commercial arts suitable for the national conditions of China. They not only created independently based on their specific expertise, but also lost no time to coordinate with Library Department of The Commercial Press and Art Museum of British American Tobacco as well as many western painters and designers in China in a fixed period, playing a decisive role in the commercial art creation at that time.

Without doubt, with the close communication with the West in early days of the Republic of China, continuous influx of a large number of Western commodities, window advertising, and American movies brought people a bizarre and motley visual perception. Relying on the direct commodities and relevant art propagation, this perception became an important feature of the period. The various products brought by advanced Western printing and industrial technologies and new materials "packaged" a brand

\footnotetext{
2 Yao Yiming. China Used Bookstore [M]. Beijing: Gold Wall Press. June 2014. p17 18.

Xia Zhengnong, Chen Zhili. Dacihai (Art Volume) [M]. Shanghai: Shanghai Lexicographical Publishing House. 2012. p.
} 488 . new "system" of commercial art. In this "system", the impact on cognition of traditional commercial art forms "obviously implied another kind of "historical truth", that is the arrival of Western modernity". ${ }^{4}$ This modernity was also enhanced by many returned overseas personnel studying art, advertising and commerce in western countries. The packaging of many industrial products also borrowed and followed the Western equipment, technology, means and expression methods, becoming the "draft" of outdoor billboards. Many designed trademarks and characters in calendar posters also became a part of the content of billboard advertising. Meanwhile, the design, drawing and application of outdoor advertising were inevitably affected by many factors under the overall influence of Western industrial and commercial arts at the time, including the promotion of different forms of Western shop window, printed matter, handicrafts, and modern imaging techniques, the combination of various commercial art forms such as western advertising and outdoor advertising, and the interaction of different commercial art forms in China such as calendar poster design, newspaper and magazine advertising, product packaging and book binding. Those factors jointly affected the design of outdoor advertising in early period of the Republic of China.

\section{THE "LOCALIZATION" ADAPTATION OF ADVERTISING DESIGN OUTSIDE CHINA}

With respect to the various outdoor advertising forms introduced and appeared in the streets in the period of the Republic of China alone, the novelty and influence brought is of no doubt. However in order to root in China, those foreign things need to be localized while retaining the foreign characteristics. Only by realizing the localization can the foreign things be truly accepted and produce a broader application space and a huge number in quantity. Regarding the creation of advertisement by foreign businessmen, due to cultural difference, many foreign firms directly put the posters, placards and calendar posters designed and produced in the West into Chinese market in the process of promoting their products. In short time, Chinese people were curious about the new things. Soon, more and more advertising posters involving cigarette, cosmetics, pharmaceuticals, bank, insurance and the like foreign things swarmed in China. Initially, Western colonists

(USA) Li Oufan, Mao Jian (trans). Shanghai Modern: The Flowering of a New Urban Culture in China, 1930-1945 [M]. Beijing: People's Literature Publishing House. 2010. p4 
were eager to expand the market, printed large amount of advertising posters in their countries and brought them to Shanghai. But when the posters were put into Shanghai, Chinese people lost the interest. Because those posters mostly showed advertisement of products on the basis of European oil painting landscapes, religions, saintess and the like things familiar to Westerners.

With vastly different national history and culture, Chinese consumers were difficult to recognize these commercial advertisements and even misunderstood the images of some advertisements. This way of advertising not only failed to play the role of promotion but increased the difficulty in selling. Forced by this situation, Western colonists began to seek a form of advertising design suitable for the national conditions of China. They discovered a simple but practical rule, that is to design and plan the advertising form and content according to the preferences of Chinese people; and a direct and effective method was adopted, namely to directly hire Chinese famous painters and commercial artists to create localized advertisement. Especially, painters famous in Shanghai at that time were selected to directly participate in the production and design because they knew better about the living habits and lifestyles of Chinese people. Before long, the advertising effect became prominent. For example, the British American Tobacco, founded in Shanghai in 1902, set up advertising department and painting room. In order to improve the design level, the company also invited more than twenty Chinese famous painters in addition to British, American, German, and Japanese painters. ${ }^{5}$ These painters created a large number of posters and guideboard and the like advertisements by combining western painting techniques with eastern figures and stories based on their specific expertise. The employment of local commercial artists helped localizing the advertising form. Furthermore, western and Chinese artists learnt mutually and improved their skills to integrate local content into western form such as combining western layout, color and figure painting methods with local stories, images and characters, producing a western and Chinese combined effect. Meanwhile in the production process of many advertising boards and pictorial posters, oriental faces

$5 \quad$ Advertising Poster Design. Section one, Chapter 15 (Art Design), Part 1 (Art Creation and Art Design), Shanghai General Annals - Professional Annals - Shanghai Art Annals [DB/OL]. http://www.shtong.gov.cn/Newsite/node2/node82538/node84939/n ode84942/node84972/node84974/userobject1 ai87025.html2007$12-08$. have begun to be used fully as main model in the picture to cater to Chinese consumers' identity.

At the same time, foreign colonists and foreign capital entered Shanghai and China to plunder and also try to weaken their foreign identity to cater to Chinese consumers and get their favor. In addition to the proactive intention of Western businessmen to seek "advertising blending and advertising harmony", some of them were also forced to make changes "unwillingly". For example, British American Tobacco once produced a type of cigarette in Shanghai named "Pirate". Western powers used the advertising slogans and patterns to boast of their images with a certain color of ostentation. The firm also felt good about this type of cigarette, and considerably advertised in some advertisements. But later, considering the anti-imperialist sentiment of Chinese people after the "Massacre of the May 30th Movement", the type of the cigarette was changed into "LaoDao" ${ }^{6}$ to ease the conflicts between China and foreign countries. This way and method indeed played a multi-faceted role. It not only helped in successful selling of Western goods on a large scale, cultivating the market and consumer groups, but also indirectly helped the integration of business and culture and the promotion of updating in a series of commercial art forms represented by outdoor advertising.

\section{THE TRANSFER OF THE FORM OF ADVERTISING INSIDE CHINA}

In the period of the Republic of China, when the completely westernized form and design of outdoor advertising spread in Shanghai, traditional Chinese outdoor advertising form did not disappear, and still retained the original form. In many researches, this situation seems to be a manifestation of inadaptability to the times and conservativeness. The author does not think so. The original form of outdoor advertising represents the existence of the original economic and consumer environment. This existence must have its unique market and acceptability. This also shows the thousands years of vitality and spirit passed down in the original form. It is not necessary to require that every form is the most fashionable. The principle of maximizing commercial interests is not equal to the principle of absolutization. The ancient culture

6 Advertising Poster Design. Section one, Chapter 15 (Art Design), Part 1 (Art Creation and Art Design), Shanghai General Annals - Professional Annals - Shanghai Art Annals [DB/OL]. http://www.shtong.gov.cn/Newsite/node2/node82538/node84939/n ode84942/node84972/node84974/userobject1 ai87025.html2007$12-08$ 
inherited in many small farming industries and commercial culture have penetrated into every pore of human nature, and these remaining outdoor advertising forms are the manifestation of these pores. It is not wise and needed to have all the original contents crushed because of the advancement of the times. As they can survive tenaciously, it is not only of historical value for many aspects of outdoor advertising but also show the inheritance of traditional commercial spirit and the awe to Chinese national culture. Therefore, it is not needed to simply or absolutely deny the ancient culture but be more grateful to and protect the witness of these ancient business cultures and leave a trace of history for the descendants.

First, the original type is the long-lived signboard. As $\mathrm{Wu}$ Tiesan records and comments, "In downtown of city, gold painted signboards can be seen here and there, including horizontal and vertical signboards, immovable and removable signboards; most of them adopt rectangular wooden plates, shiny black paint base and raised golden characters in regular script or clerical script or few seal script". ${ }^{7}$ In old outdoor advertising, signboard was applied extensively and generally and adopted different writing content as per specific industry and business scope; but basically it adopted rectangular shape, and golden characters on black background; some of the signboards adopted "black characters on white background, red characters on white background, blue characters on white background, and golden characters on white background". Most of them are placed horizontally, regardless of mechanical beauty. But the two kinds of beauty are both in use now. This is more creative. Space was originally not noticed, but now is being used. This is a kind of progress. In addition, contrast colors are also in use, producing new visual effects. ${ }^{8}$ The oriental characters mentioned by $\mathrm{Wu}$ Tiesan embody the "art of calligraphy" in type setting, while the western characters are "neat and coordinated." In his opinion, these views can all become juxtaposed designs and form the original creation on this basis. Of course, these viewpoints can also be regarded as the cognition under the overall development context of the era. These changes had even formed a trend and run in various outdoor advertising designs at that time.

The other form is that traditional advertising forms are actively responding to changes in the times,

\footnotetext{
Wu Tiesan. Discussion on Old Advertising in Shanghai. Shanghai City Archives. File No. Q242-1-828.

Wu Tiesan. Discussion on Old Advertising in Shanghai. Shanghai City Archives. File No. Q242-1-828.
}

resolving some of their disadvantages and integrating them into modern new outdoor advertising design, forms and concept. Although the integrated outdoor advertising form may not be able to compete with the fully westernized outdoor advertising form most directly and beneficially, it can still witness the changing characteristics of traditional outdoor advertising in design and concept in this period. These characteristics have been improved. The form and content of some outdoor advertising have been improved to be very different from the original form. But they are still an important aspect of the outdoor advertising form in Shanghai in the period of the Republic of China, and also make the outdoor advertising more diversified. For example, the signboard of Wang Shunchang, a Hongbang tailor shop on West Nanjing Road, adopted completely new design and production method. Western fonts and typesetting methods had been placed in the main position, and English words had been extensively used and in modern reading mode "from left to right", while the Chinese characters "Wang Shunchang" were only embodied on two sides of the main door head. In this signboard, Chinese characters and English words are placed in the same place, combine with the publicity slogan of the front pillar and the towering vertical signboard in front of the door, which not only embodies that the shop is a Chinese shop, but also shows the Western design form. Similarly, the "Xiechang" clothing shop on West Nanjing Road also adopted the combination of Chinese and English. Not only the production of signboards in this period represents the skillful use of the combination of Chinese characters and English words, but also the popularity of this "combination design" shows that the outdoor advertising design at that time had accepted Western design concept and get it well integrated into the current design.

Of course, the main purpose of the Chinese and Western operators in adopting advanced outdoor advertising forms is not only to indicate their businesses, but also to expand sales. With the same fundamental purpose, the embodiment ways and expression methods of advanced Western business ideas are more accurate and appropriate, and are more in line with modern science and modern business ideas. Then for Western outdoor advertising with greater commercial value, it is not strange that such advertising was quickly accepted and absorbed by Chinese traditional businessmen. Businessmen will not consider whether it is traditional or Western, but only recognize the form that can bring them more profits. 


\section{CONCLUSION}

After the introduction of Western advanced and diversified advertising concepts in Shanghai, many traditional Shanghai industries and operators recognized the value and charm of them, and began to accept, cater to and adapt to the advanced advertising forms introduced from the west. Many outdoor advertising began to adopt Western design forms and patterns; and modernized materials and techniques were introduced into traditional commercial fields, giving outdoor advertising new vitality in traditional forms, and also bringing a brand-new space for the original commercial system.

\section{AUTHORS' CONTRIBUTIONS}

This paper is independently completed by Huang Zhan.

\section{REFERENCES}

[1] Wu Tiesan. Discussion on Old Advertising in Shanghai. Shanghai City Archives. File No. Q242-1-828. 1934. (in Chinese)

[2] Advertising Poster Design. Section one, Chapter 15 (Art Design), Part 1 (Art Creation and Art Design), Shanghai General Annals - Professional Annals - Shanghai Art Annals [DB/OL] 2007.12.08. (in Chinese)

[3] Chen Xiangbo, Xu Ping, Zhou Bo, Huang Zhicheng; Guanshanyue Art Museum, Central Academy of Fine Arts. Documentary of the 20th Century Chinese Graphic Design [C]. Guangxi Fine Arts Publishing House. May 2012. (in Chinese)

[4] Yao Yiming. China Used Bookstore [M]. Beijing: Gold Wall Press. June 2014. (in Chinese)

[5] Xia Zhengnong, Chen Zhili. Dacihai (Art Volume) $\quad[\mathrm{M}]$. Shanghai: Shanghai Lexicographical Publishing House. 2012. (in Chinese)

[6] (USA) Li Oufan, Mao Jian (trans). Shanghai Modern: The Flowering of a New Urban Culture in China, 1930-1945 [M]. Beijing: People's Literature Publishing House. 2010. (in Chinese) 